\title{
A Dramaturgical Examination of Online University Student Practices in a Second Year Psychology Class
}

\author{
Dawn Marie Gilmore \\ RMIT Online
}

\begin{abstract}
This study employs dramaturgical analysis, the study of social interaction in terms of theatrical performance, in examining online student interactions. Region-specific activity - front stage (the course LMS) versus backstage (Facebook) - was examined to determine where students spend their time doing class-related tasks. The context for this case study is a second-year online psychology class at an Australian university. Data were collected concerning students' courserelated activities in the two venues. Over a 12-week semester, 126 students were observed in the LMS. Twenty-one students completed fortnightly questionnaires about where they spent their time and with whom. At the end of the semester, 14 students participated in online interviews. Findings suggest that the audience in each setting, as well as the timing of communication and duration within each setting, appear to have contributed to shaping students' learning experiences. Awareness of these contributing factors may aid online teachers in understanding students' learning preferences, and the roles of social networking tools in supporting learning collaborations.
\end{abstract}

Keywords: online learning, online teaching, student experience, Facebook, Goffman

Gilmore, D.M. (2020). A dramaturgical examination of online university student practice in a second year psychology class. Online Learning, 24(1), 264-281.

https://doi.org/10.24059/olj.v24i1.1988

\section{A Dramaturgical Examination of Online University Student Practices in a Second Year Psychology Class}

Dramaturgical sociology views human interactions determined by time, setting, and audience (Goffman, 1959). Goffman's approach advocates that one must not analyze the cause of human interactions, but instead examine contexts in which those interactions occur. Goffman (1959) uses theatrical metaphors, specifically the stage: front stage (where the actors perform for an audience) and backstage (where the actors prepare for the performance). This study considers the learning management system (LMS) as the front stage and Facebook as the backstage and examines how and why online students use backstage online settings, such as Facebook, instead of front stage settings, such as the LMS, to support their university learning. A second-year online psychology class was selected as the case due to its large class size and the fact that students were familiar with online learning and social media. Online observations, questionnaires, and interviews were employed to understand students' front stage and backstage learning experiences. 
A Dramaturgical Examination of Online University Student Practices in a Second Year Psychology Class

\section{Facebook and social learning in the university context}

Facebook is a popular social networking tool among university students. Junco (2014), for example, found that university students spend over an hour a day using Facebook for university purposes. The three main ways to express presence on Facebook are through individual profiles, pages, and groups. A Facebook profile is a personal account where an individual can connect with friends, see other friends' posts, share their own thoughts, and share photos or links to internet sites. Facebook pages, on the other hand, are for official individuals (like Taylor Swift) or businesses to share stories and connect with people. In the university context, a university might have an official page and students would "like" the page. Then updates from the page would appear on individual users' Facebook feeds. Universities have successfully used official Facebook pages to integrate new students into academia before course registration (Lin, Hou, Wang, \& Chang, 2013). There are also Facebook groups, which are settings for a small group or community to converse and share information. In one study, students reported being members of five or six university-related Facebook groups. These included groups for primary school alumni, political affiliations, hobbies, sharing opinions on current topics, having academic conversations, and sharing learning materials (Bosch, 2009). Groups can be publicly available, for anyone to join, or privately available where those who join must be approved by an administrator.

The affordances to communicate synchronously through Facebook messaging, asynchronously through wall posts, as well as commenting on and sharing information, are features that make Facebook ideal for social learning. While the blurring of lines between social networking and university learning has been criticized by some students (Donlan, 2014) and teachers (Prescott, Wilson, \& Becket, 2013), others believe the inherently social nature of such sites supports learning. Indeed, studies surveying students found that they feel Facebook has the potential to promote collaborative and cooperative learning (Arouri, 2015; Bicen \& Cavus, 2011; Roblyer, McDaniel, Webb, Herman, \& Witty, 2010). Social learning theories see learning as generated through the observation of others and through direct experiences with others - two modes that Facebook tools afford. In their theory of situated learning, for example, Lave \& Wenger (1991) refer to this phenomenon as legitimate peripheral participation (LPP). LPP is the process of observing others before direct social interaction with others. By observing others, students can learn about behaviors and their consequences as well as reap the benefits of any information shared while observing others' social interactions. Once a learner moves beyond LPP they can chose to take a more visible role in the group, however this is not a requirement of continual learning.

Lave \& Wenger (1991) suggest that situated learning occurs when a group is made up of novices and experts, or newcomers and old-timers. The mixed abilities create opportunities for more experienced members to share their knowledge. An expert or old-timer can also be referred to as a more knowledgeable other (Vygotsky, 1978; Wenger, 1998). When students are surrounded by peers of various knowledgeability, they are afforded opportunities to go beyond the content that was scaffolded for them in the design of the curriculum. This is advantageous for students whose needs may not be being otherwise met. As one study suggested, learning backstage on Facebook was the result of a student's inability to find information and not understand content, assessments, or course administration (Cuesta, Eklund, Rydin, \& Witt, 2016). This suggests that information seeking performed by a novice and information sharing performed by an expert or more knowledgeable other occurred. In several studies students reported that Facebook posts that asked questions that grew into discussions were beneficial to their learning (DiVall \& Kirwin, 2012), particularly when the responses came from a 'more knowledgeable other,' such as the teacher 
A Dramaturgical Examination of Online University Student Practices in a Second Year Psychology Class

(Rambe, 2012) —again illustrating how cohorts of mixed abilities can support learning. In addition, one study found that Facebook posts about not understanding were balanced with responses of understanding by a 20:18 ratio (English \& Duncan-Howell, 2008). This suggests that more knowledgeable others were present and willing to share their experiences and knowledge.

While expert presence may be viewed positively, it can also be disruptive. Rambe (2012) found that students abstained from answering classmates' Facebook posts related to content and waited for a teacher to respond. In this instance, students viewed the content-related posts as the teacher's domain (Rambe, 2012). Similarly, in Facebook groups with both postgraduates and undergraduates present, the postgraduates posted the most and the undergraduates posted the least (Ru-Chu, 2013). When experts, such as a teacher or older student, are present on the Facebook page, the students might defer to the expert and self-identify areas where they should not answer, even if they can. There was, however, one exception to this. (Bowman \& Akcaoglu, 2014) found that "super-users" responded to classmates regardless of whether they knew the answer. With the exception of "super-users," students may be aware that more knowledgeable others are present and defer to them.

Students can also use situated learning to learn how to be a university student while learning course content. Learning to be a student involves knowledge-seeking or knowledgesharing as regards course management, academic codes, and course requirements, particularly those related to assessments (Bowman \& Akcaoglu, 2014; Cuesta et al., 2016). Learning content, on the other hand, involves seeking or sharing an understanding of content specific to a particular class. Learning-content posts, for example, can include links from class materials to current events (Bosch, 2009; Staines \& Lauchs, 2013), political thought (Hyde-Clarke, 2013), as well as work experiences (English \& Duncan-Howell, 2008). Overall Facebook posts about learning-to-be-astudent consistently outnumbered Facebook posts about learning the knowledge of a content area and, even when students' used Facebook independent from their class, they continued to seek and share information related more to assessments than the content knowledge (Selwyn, 2009). Nonetheless, as these studies demonstrate, few studies explore why students migrate towards online social spaces beyond the course. The studies only viewed students in one context, the Facebook context. Similarly, in studies of education it is common for researchers to only explore the formal education setting (Livingstone \& Sefton-Green, 2016). The intent of this paper, however, is to explore student interactions in both settings. To achieve this, I employ Goffman's (1959) region-based behavior as the theoretical lens. The next section describes this approach and how it was applied across the two contexts.

\section{Theoretical Approach: Goffman's (1959) region behavior}

In dramaturgical sociology, region behavior occurs in any place defined by cultural perception. Borrowed from theater, Goffman (1959) metaphorically employs two regions of social behavior, the front stage and the backstage, as a means of analyzing social behaviors. In the front stage, an actor is putting on a performance and is conscious of being observed by others. In the backstage, an actor is afforded privacy from those in the front stage. The backstage is a place for preparation for front stage performance and a place to seek reprieve. In Goffman's 1959 study of the Shetland Hotel, he identified the dining room and parlor as the front stage. This was the space where guests and hotel staff interacted with each other. In this space, both employees and guests behaved according to British middle-class norms. But in the backstage, the kitchen, the employees behaved according to Shetland Islander norms. This meant that acceptable food, attire, and behavior in the backstage was different to that of the front stage. For example, it was acceptable 
A Dramaturgical Examination of Online University Student Practices in a Second Year Psychology Class

to wear a hat, hang socks over the stove to dry, spit in a cup, and keep moldy soup in the backstage. However, in the front stage, staff maintained a polished appearance and the presence of mold was unacceptable.

Goffman's (1959) overall observation was that an employee's front stage (in the restaurant) and backstage (in the kitchen) was parts of the whole individual separated by a kitchen door. Technology, the door, played an important role in situating behavior within the spaces of the hotel. Behaviors the hotel managers did not want the hotel customers seeing remained hidden behind the door in the backstage. One of the main parameters of Goffman's body of work is co-presence of participants. In recent times, however, technology has come to simulate a co-presence between people. In online studies, however, not studies of university students, Goffman's region behaviors have been applied to produce a fuller account of how internet users engage across the backstage and front stage spaces (Bullingham \& Vasconcelos, 2013; Hogan, 2010; Pearson, 2009; Ross, 2007; Trammell \& Keshelashvili, 2005). Bullingham \& Vasconcelos (2013) argue that blogs and avatars are online environments, which could be the front stage to an offline backstage.

If the LMS is identified as the front stage, then all other environments that a student uses to prepare for their performance there combine to form the students' backstage learning environment. A front stage is typically marked by the decorum of those present, not the space. In the Shetland Hotel example, the front stage was marked by middle-class norms and the backstage Shetland Islander norms. However, the backstage kitchen was not totally hidden from the front stage dining area. The door, which separated the stages, could be propped open at times by waitstaff who were carrying heavy trays. This permitted customers the opportunity to glimpse into the kitchen. It did not suddenly turn the kitchen into a momentary front stage. By comparison, Ross (2007) studied London cabbies-in-training who used public online message boards as a backstage to their front stage in-person cabbie training. The backstage was an online community for learners, created by learners, with an occasional outsider passing through. The online backstage afforded cabbies a space to feel connected by using informal language, share resources that made learning possible, as well as anonymity that made critiquing actors from the front stage (examiners, customers, colleagues) possible.

In the context of the current study, for students taking formal online courses the LMS, the frontstage, is considered the central locus of learning. It provides space and tools where students and teachers can store and access learning materials, to communicate on discussion boards, and to submit assignments. As in the case of the Shetland Hotel where the door mediated the roles actors played between the dining room and the hotel kitchen, the LMS mediates the role of students and their interactions. Questions and statements posted to a front stage discussion board can be viewed by everyone in the course. If this public action induces feelings of stage fright, this may discourage further posting. That does not mean the question ceased to exist or went unasked. It could indeed get asked in a backstage venue. Facebook is often used a backstage where university students can interact out of view from teachers and staff, and essentially learn how to be university students (Selwyn, 2009).

For the purpose of this study, the front stage is defined as the space where an online student gives a performance-the LMS. Actions in the LMS front stage space can be "seen" by the university, whether through the online discussion board or through student activity logs. The backstage is the space where an online student prepares for a performance. This study examines what students do beyond the LMS and how social media spaces preferred by students afford social learning and enrich the student experience. 
A Dramaturgical Examination of Online University Student Practices in a Second Year Psychology Class

\section{Methods}

This research employs a constructivist paradigm in that it examines participants' lived experiences (Waller, Farquharson, \& Dempsey, 2016). Researchers applying this paradigm accept that reality is socially constructed from the participants' point of view. Meaning is not taken for granted and interpretations of actions are based on how those we study define the situation (Denzin, 1989). While the findings are thus limited to the cohort studied, findings and their interpretations can nonetheless inform theory, research, and practice (Stake, 1995).

Data were collected through observations, fortnightly questionnaires, and interviews. In the first week of the course, the teacher announced that I would be observing for research purposes and encouraged students to participate in the research. Over a 12-week semester I observed 126 students in the front stage LMS. Of the 126 students, 21 students opted to complete fortnightly questionnaires that prompted the students to report where they spent their time completing classrelated-tasks in the backstage, and with whom. At the end of the semester, 14 students chose to participate in an online interview. All data collection procedures were conducted in accordance with the university human ethics guidelines of the university. In the three sections that follow, I include a brief description of each approach.

\section{Observations}

Being enrolled in the LMS as an observer enabled me to take in the scene of the research setting - specifically the participants' front stage. I knew what students were being asked to do and when, including reading the weekly learning materials, activities, and assessments. I observed students' responses to the weekly activities and conversations that occurred in the discussion boards. If the teacher sent a group email, I also received the email. My observations of the front stage contributed to my understanding of the data generated from the backstage in the Facebook context.

\section{Questionnaires}

Fortnightly questionnaires were used to collect data about students' content-related tasks and study habits over the twelve-week semester. Each fortnight students were asked to recall where they went to seek and share information related to the course, who they interacted with, and for how long they did each of these actions in the front stage and backstage.

\section{Interviews}

Interviews gave participants the opportunity to give voice to their front stage and backstage data. Interviews were transcribed, uploaded to NVivo and coded by applying Braun \& Clarke's (2006) guidelines for thematic analysis. To assure trustworthiness I participated in member checks and triangulation between the three data types (see Stake, 1995). The students who participated in the questionnaire and interview were a mix of part-time and full-time enrolments and ranged in age from 21 to 73 years old. They were also from a variety of locations around Australia, including major cities like Melbourne and remote areas like far north Queensland.

\section{Setting: A second year university psychology class}

This research was conducted in an online second year psychology class at an Australian university, which offers both face-to-face and online degrees. This course was part of a fully online bachelor's degree in psychology. The online students are awarded the same qualifications as the on-campus students. The class was delivered using the Blackboard Learning Management System 
(Blackboard), which afforded students and teachers two main functions: access to course content and communication. The course content function allowed students to access learning materials such as articles, assignments, and videos. These learning materials were organized into twelve weekly learning modules. Each week covered one theoretical approach to counselling, which included a video of a patient receiving counselling and a discussion board activity. The communication function allowed for both asynchronous and synchronous communication between teachers and students. The class also used a live conferencing tool called Collaborate to host onehour weekly tutorials.

Participation in discussion board forums was not graded; however, the syllabus stated that students were expected to contribute to the discussion board forums on a regular basis. Three total contact hours were prescribed for the course, which included two hours per week completing the learning materials, and one hour per week participating in a synchronous Collaborate tutorial (or watching the recording of those who participated). One unit coordinator and four tutors taught the class. The teaching team was responsible for monitoring the discussion board forums, marking students' assessments, and running the weekly Collaborate sessions.

\section{Results}

Consistent patterns in the students' participation emerged in the front stage observation data. In order to illustrate this, I characterized the students into four front stage typologies: performers, extras, cameos, and stagehands. The typologies not only describe the participation patterns, but also extend Goffman's (1959) theater terminology (front stage, backstage, actors, props, setting). Table 1 describes the performance patterns observed in the front stage.

Table 1

Description of Front Stage Roles

\begin{tabular}{|c|c|}
\hline Front stage role & Description of the front stage performance patterns \\
\hline Performer & Posted weekly, or more, to front stage discussion boards \\
\hline Extras & $\begin{array}{l}\text { Occasionally posted to the front stage discussion board, } \\
\text { participation was consistent at the start and tapered off }\end{array}$ \\
\hline Cameos & $\begin{array}{l}\text { Made brief appearances in the front stage discussion board. This } \\
\text { was typically to introduce themselves or ask one question about } \\
\text { one assessment }\end{array}$ \\
\hline Stagehands & Never posted to the front stage discussion board \\
\hline
\end{tabular}


A Dramaturgical Examination of Online University Student Practices in a Second Year Psychology Class

Table 2

The Breakdown of Students in the Psychology Class and Total Participants in the Fortnightly Questionnaires and Interviews

\begin{tabular}{cccc}
\hline $\begin{array}{c}\text { Level of } \\
\text { participation }\end{array}$ & $\begin{array}{c}\text { Total students } \\
\text { enrolled in the } \\
\text { class }\end{array}$ & $\begin{array}{c}\text { Total participants } \\
\text { in fortnightly } \\
\text { questionnaires }\end{array}$ & $\begin{array}{c}\text { Total participants } \\
\text { in interviews }\end{array}$ \\
\hline Stagehand & 44 & 7 & 3 \\
Cameo & 45 & 6 & 4 \\
Extra & 23 & 4 & 3 \\
Performer & 13 & 4 & 4 \\
\hline Total students & $\mathbf{1 2 6}$ & $\mathbf{2 1}$ & $\mathbf{1 4}$ \\
\hline
\end{tabular}

Source: Front stage observation data

Table 2 shows the breakdown of performers, extras, cameos, and stagehands in the psychology class. A variety of participation levels were present in the study. In addition, participants who completed questionnaires and interviews were well represented across the participation levels. Out of the 126 students, a total of 44 were stagehands and therefore never posted to the discussion board, and only 13 were performers. Most students rarely, if ever, posted to the discussion board in the front stage.

Interestingly, Table 2 illustrates how those students who had the highest representation in the study, the stagehands, had the lowest representation in the front stage discussion board. This participation pattern could be used to support the suggestion that a student's front stage data, such as posting to the discussion board or hours spent logged into the front stage, may not be an indicator of engagement in the online class. This was further supported by Table 3, which compares the average hours students spent in the front stage compared to the time students reported using to complete class-related tasks in the backstage.

Table 3

Average Hours that 21 Participants Performed Class-related Tasks over 12 Weeks

\begin{tabular}{cccc}
\hline $\begin{array}{c}\text { Level of } \\
\text { participation } \\
\text { (the cast) }\end{array}$ & $\begin{array}{c}\text { Average hours online } \\
\text { in the front stage }\end{array}$ & $\begin{array}{c}\text { Average hours } \\
\text { backstage online }\end{array}$ & $\begin{array}{c}\text { Total Average } \\
\text { online hours }\end{array}$ \\
\hline Stagehands & 10 & 27 & $\mathbf{7 4}$ \\
Cameos & 9 & 17 & $\mathbf{6 3}$ \\
Extras & 28 & 59 & $\mathbf{1 4 2}$ \\
Performers & 75 & 34 & $\mathbf{1 4 5}$ \\
\hline Total & $\mathbf{1 2 2}$ & $\mathbf{1 3 7}$ & $\mathbf{4 2 4}$ \\
\hline
\end{tabular}

Source: LMS data and questionnaire data 


\section{Backstage online Facebook groups and friends}

As shown in Table 3, stagehands, cameos, and extras spent almost twice the amount of time in the entire online backstage (not just Facebook) when compared with the front stage. Although the times reported in Table 3 are not a measure of learning or engagement with the class, it does help to identify contexts where students might prefer to learn or engage within an online class. Responses to fortnightly questionnaires indicate that students were engaged in backstage online spaces such as the university library, Google Scholar, and YouTube; however, interviews reveal that the most popular space that stagehands, cameos, and extras used for learning in the online backstage was Facebook. The Facebook groups and the purpose students described are summarized in Table 4 below.

\section{Table 4}

Facebook Groups and Descriptions

\begin{tabular}{|c|c|}
\hline Facebook Groups & Purpose \\
\hline Social Science Majors (Closed) & $\begin{array}{l}\text { A student group for all majors in the } \\
\text { social science faculty at this university } \\
\text { only. For learning content and learning } \\
\text { to be a student. }\end{array}$ \\
\hline Psychology Majors Only (Closed) & $\begin{array}{l}\text { A student group for psychology majors } \\
\text { that enrolled at this university in the } \\
\text { same year. For learning content and } \\
\text { learning to be a student. }\end{array}$ \\
\hline $\begin{array}{l}\text { Individual study groups related to } \\
\text { specific class (Closed) }\end{array}$ & $\begin{array}{l}\text { A small student group organized to } \\
\text { study together for a specific class or } \\
\text { complete tasks together }\end{array}$ \\
\hline $\begin{array}{l}\text { Social Facebook groups unrelated to } \\
\text { the university (Public) }\end{array}$ & $\begin{array}{l}\text { A public support group for any tertiary } \\
\text { student at any institution for example: } \\
\text { UNI Coffee Shop. For learning to be a } \\
\text { student. }\end{array}$ \\
\hline $\begin{array}{l}\text { Content Facebook groups or groups } \\
\text { unrelated to the university (Public) }\end{array}$ & $\begin{array}{l}\text { A public Facebook group for people } \\
\text { interested in learning about content of } \\
\text { their choice for example: The Glasser } \\
\text { Institute. For learning content. }\end{array}$ \\
\hline Facebook friends from this university & $\begin{array}{l}\text { Some students made one-to-one } \\
\text { friendships and shared study and social } \\
\text { or personal information like family } \\
\text { photos. For learning to be a student, } \\
\text { learning content, and social. }\end{array}$ \\
\hline
\end{tabular}

Source: Interview data 
In dramaturgical sociology, elements of human interaction depend on audience, time, and setting (Goffman, 1959). These factors also shape social learning experiences in online courses. Explicated illustrations of each follow.

\section{Audience size and attributes in the front stage and backstage}

Most students reported being members of both the Social Science Majors and Psychology Majors groups. The Social Science Majors group was the largest of the groups, with over 600 members, and the Psychology Majors group had over 130 members. The discussion board in the LMS also had 126 members, but only 13 of those students were performers. Table 5 lists the characteristics from the interview data that students used to describe each audience. The most notable difference between the front stage and backstage audiences was the presence of teachers in the front stage and the presence of peers with a variety of experience levels in the online backstage.

Table 5

Students' Descriptions of the Front Stage and Backstage Audiences

\begin{tabular}{l|ll}
\hline Front stage discussion board audience & Backstage online Facebook audience \\
\hline - $\begin{array}{l}\text { Teachers who only log in at } \\
\text { certain times of day }\end{array}$ & $\begin{array}{l}\text { Peers from the same class (near } \\
\text { peers) }\end{array}$ \\
$\begin{array}{l}\text { Teachers who give harsh feedback } \\
\text { or request students to relocate }\end{array}$ & - $\begin{array}{l}\text { Peers who have completed this class } \\
\text { discussion board posts }\end{array}$ \\
$\begin{array}{l}\text { Teachers/university staff who } \\
\text { have vetted learning materials }\end{array}$ & - $\begin{array}{l}\text { Peers who are now friends (two } \\
\text { years' time) }\end{array}$ \\
$\begin{array}{l}\text { Teachers/peers who may not } \\
\text { respond or respond too late to } \\
\text { questions or completion of tasks }\end{array}$ & - $\begin{array}{l}\text { Peers who have vetted resources for } \\
\text { learning }\end{array}$ \\
$\begin{array}{l}\text { Peers and teachers who write } \\
\text { using formal language and big }\end{array}$ & $\begin{array}{l}\text { Peers from various class but on the } \\
\text { same academic calendar }\end{array}$ \\
$\begin{array}{l}\text { words } \\
\text { Peers in this class only (12 weeks } \\
\text { time) }\end{array}$ & $\begin{array}{l}\text { Peers who have around the clock } \\
\text { access and easily accessible } \\
\text { Peers who make off-topic posts } \\
\text { making the discussion board } \\
\text { unwieldy }\end{array}$ \\
\hline
\end{tabular}

Source: Interview data 


\section{Discussion}

There is a marked difference between the ways online students present themselves front stage in the LMS and backstage in Facebook. Through the lens of Lave and Wenger's (1998) social learning theory, which suggests that learning occurs across space and time in multiple contexts, and Goffman's (1956) approach of region behavior, we see that students with low front stage participation were active and engaged in the backstage. Discussion of these practices is organized into four sections: (a) time and social learning experiences; (b) students' perceptions of tutors; (c) speed; and (d) a sense of belonging.

\section{Time and social learning experiences}

For some students, time may be an important factor that supports or impedes learning. Overall, students reported spending more time in the online backstage than they spent in the front stage. The exception to this finding was the Performer cohort, who perpetually logged into the front stage for fear of missing out on information that could be important. This group also acted as first-responders, being the first to respond to questions or tasks, as well as the first to offer encouragement to classmates. In studies of Facebook usage, Bowman (2014) referred to these students as super-users because they respond to students even when they don't know the answer. This was the also the case in the front stage discussion board. Super-users responded to almost every post by a student or teacher. Ingrid, for example, was a super-user who posted fifteen times more than the average student, which made her responsible for $15 \%$ of the 1,430 posts in the front stage:

This [front stage] is my friendly place, where I feel part of something, not all alone at my desk, looking out at the horrible gray walls of the house next door. I think I have gained as much from various discussion boards as from all my other reading...

Ingrid uses "friendly" to describe her feelings of connectedness and sense of belonging in her studies. Ingrid did not have a Facebook account because she felt that the discussion board was enough to support her learning experience in the class. Like Ingrid, most of the performers were not on Facebook because they felt that their sense of belonging was fulfilled by their active presence in the front stage.

While students like Ingrid may be inherently social, other students may need more time to develop social ties that support their learning experience. In which case, time may be an important aspect between the front stage and backstage that impacts a social learning experience. The timing of communication, such as whether communication occurs synchronously or asynchronously, affords distinct behaviors (Hogan 2010). And in this case, the length of time in a space may have even impacted whether communication occurred at all. The online class ran for twelve weeks but some students were in the university Facebook groups for as long as two years or more. The ephemeral nature of the online class may afford students the time needed to negotiate their role in each space. In the front stage, a stagehand remained constant for the twelve weeks, whereas a cameo or extra tapered off around week 3. Table 6 shows how participation in the front stage significantly dropped off between weeks one and four. This decrease in participation suggests that learning may have shifted to a backstage. 
A Dramaturgical Examination of Online University Student Practices in a Second Year Psychology Class

Table 6

Participation Rate by Week

\begin{tabular}{ccccccccccccc}
\hline $\begin{array}{c}\text { Weeks in the front } \\
\text { stage }\end{array}$ & $\mathbf{1}$ & $\mathbf{2}$ & $\mathbf{3}$ & $\mathbf{4}$ & $\mathbf{5}$ & $\mathbf{6}$ & $\mathbf{7}$ & $\mathbf{8}$ & $\mathbf{9}$ & $\mathbf{1 0}$ & $\mathbf{1 1}$ & $\mathbf{1 2}$ \\
\hline $\begin{array}{c}\text { Total students } \\
\text { posting in the front } \\
\text { stage per week }\end{array}$ & 37 & 23 & 23 & 14 & 12 & 11 & 9 & 6 & 6 & 6 & 4 & 1 \\
\hline
\end{tabular}

Source: Front stage observation data

In the large backstage Facebook groups most of the students described changing their participation trajectories in Facebook from stagehand to performer. Kara recalled being invited to the Social Science Facebook group during her first semester via a front stage discussion board post. She joined the Facebook group and, at first, only observed. As an observer in the Facebook group, Kara became acquainted with members from the Social Science Majors group because their names frequently appeared in her everyday Facebook feed. After six months of observing she began posting to the community because she felt more connected there than she did in the discussion board:

I didn't really interact much at first. It is probably more after 6 months as the same names keep cropping up. We post a bit of everything [related to psychology] and sometimes just letting off steam over marks.

The process that Kara describes is a typical first step in social learning. Lave \& Wenger (1991) suggests that all learning begins with legitimate peripheral participation before learners feel confident enough to participate as a newcomer, near peer, or expert. Despite being at the university and in the Facebook group for the same number of years, Kara was a stagehand in the front stage but described herself as an extra, if not a performer, in the online backstage. This, though, took her six months to achieve. This suggests that the length of a course may not be sufficient for some learners to establish a sense of trust, belonging, and the ability to negotiate their roles and interactions with others-all features which Wenger (1998) argues are conditions for social learning. This was the case for some extras, Briana and Julia, who describe how over time they made Facebook friends from their online university class who helped to support their social learning in the backstage:

Fortunately I have established online relationships with people throughout this degree and they aren't necessarily in my current unit but may have completed and are often happy to discuss things via Facebook through inbox and also through Facebook on the main group for [Social Science Majors and Psychology Majors Only]. (Briana, Extra)

I became friends with two ladies [from a previous class]. One's in Townsville and Cairns. We'd brainstorm forever...We message through Facebook. Actually one day I talked [to the one friend] for three and a half hours. So that works better than the discussion board in my personal situation. (Julia, Extra) 
As a result of participating in Facebook groups, most of the students reported making Facebook friends who supported their learning experience. Bosch (2009) found that it was common for university students to be members of multiple university-related Facebook groups. One stagehand was simultaneously a member of the Social Science Majors group, the Psychology Majors Only group, a Facebook group for every class she enrolled in (past and present), and a Facebook group unrelated to the university about positive mental health counselling (the topic of the class). In addition to these groups, she has Facebook friends whom she met over the last three years of her university study. Most of the students interviewed were in more than one Facebook group, which may have increased their chances for finding relationships where they felt a sense of belonging, trust, and negotiation. Facebook provided multiple contexts for students to apply their learning, related to the psychology class, with others over time.

\section{Students' perceptions of tutors in the front stage}

Audience and time clearly shape social interactions. In the case of course tutors, some students described feedback as too slow, too harsh and sometimes disruptive to conversations that could have contributed to a student's understanding (see Table 5.). Stagehands, and to some extent extras and cameos, self-segregated themselves confirming Goffman's observation that front stage control is often one measure for audience segregation. Through segregating oneself from the front stage, actors can escape or buffer themselves from those aspects of a setting they find unpleasant (Goffman, 1959). This is a useful way to explain students' absence in the front stage. It might also explain sudden decreases in front stage participation. Kathy, an extra, was the leader for a small Facebook group of students who were unhappy about the class. Kathy described tutor feedback on assessments as "harsh." She also reported tutors asking her to move discussion board posts from one discussion board forum to another. This happened to various students in the class on six occasions. In each instance the conversation that had been interrupted ended and the student did not post to the discussion board again. Kathy describes this disruption:

Kathy (Extra): I went on the discussion board and asked about ethics. About an experience I wanted to know about a psychiatrist... and one of the tutors was awesome about it and was telling me the procedure, but then another tutor said, "Ah, this shouldn't be on this discussion board, it should be just on the other discussion board. Did you want to move this conversation there?"

Interviewer: Was that the end of the conversation?

Kathy (Extra): Yep, I was talking to the other tutor, and she was like, talking about the ethics of it, and it was fine, but then the other tutor just like totally cut us off...I...I [also] put it on there [the discussion board] is there anyone in the Gold Coast who wants to study and meet up and... and then um, the tutor was just like "Oh, can you put this on the other... another discussion board" or something... I was like "Oh, okay". I just...I didn't post it to the other one. I just thought...well, I gave up.

Interviewer: Did any of your classmates respond to you about meeting up?

Kathy (Extra): No.

Kathy eventually stopped posting in the front stage altogether. By week 4, her discussion board participation ceased but her backstage Facebook participation increased. Goffman (1959) suggests that actors who go backstage are afforded opportunities to derogate the audience and that 
the discussion in the backstage can often turn towards problems of staging. Interestingly, students explained how these backstage conversations eventually evolved into learning opportunities. In Kathy's case, she found a group of students from the Psychology Majors Only Facebook group that were upset about technology problems and class assessment feedback. Initially, these students bonded over their negative experiences in the front stage. Subsequently they created an individual Facebook group for the psychology class. In this group, they worked through weekly activities together and studied for the final exam together. Kathy preferred this space instead of the discussion board:

Um, just I liked talking on Facebook more than the discussion board. I was able to learn from my classmates in that way. Yes, um, we completed the tasks [from the front stage] they [my classmates] also sent videos out on Facebook, like examples, like YouTube videos of different counselling methods.

Kathy's experience studying in a Facebook group was not uncommon. A total of four small separate study groups (containing 2-5 students) were reported during interviews and two more Facebook study groups were referenced by students in discussion board posts. While perceptions of their tutor may not be the only reason for their segregation into the backstage it does highlight the impact of teaching presence in online courses. As studies of Facebook show, students can seek and find information from those who make them feel more comfortable.

\section{Students' perceptions of speed}

In addition to self-segregating for the purposes of having small study groups, students also preferred Facebook based on their perception of the speed of responses to posts. Overall, speed of responses was reported as faster in the backstage Facebook groups. During interviews students echoed repeatedly that information was faster in the backstage online.

My first step was [the] Discussion Board and I had to wait because responses are slow. Facebook was the second step. [But I preferred] the Facebook group because the responses were quicker and also more personal. (Briana, Extra)

There are several reasons why the backstage audience was perceived to be faster than the front stage audience. In the front stage, conversations may have been "slow" for reasons found by Rambe (2012): if students view certain posts as a teacher's domain this could slow down the responses in the front stage. However, if teachers are not present, like in the backstage Facebook groups of this study, then the behavior in the setting changes or in this instance the communication was "quicker":

...there are quite a few really good YouTube channels that have ex professors and teachers and they are really good they explain things without treating the audience like a brainless dolt. Usually videos from Facebook were always good because another classmate already used it......that is one of the great things about the Facebook groups the sharing of links to extra material that sometimes help understand a class or concept [from that week]... (Kara, Stagehand)

Resources in the backstage, such as videos, were vetted by more experienced students who had already completed the class and understood what it was like to be a student in that class. This supported students taking control of their learning experience in terms of time and access. 
A Dramaturgical Examination of Online University Student Practices in a Second Year Psychology Class

\section{Students' perceptions of belonging}

Belonging emerged as a theme absent from prior research on Facebook in the university context. In the data, students reported and described a sense of belonging in the backstage that was not present in the front stage. Students in the backstage developed a "less formal" and more "comfortable" setting:

Facebook was good actually, because you could post bits and pieces and whatever. It felt less formal than the discussion board. Even though we were probably talking about the same thing, but to me personally, it felt less structured. Less academic, is probably the word I am looking for. (Julia, Extra)

I am not comfortable posting on DB. I think there is the fear of making an idiot of myself but that is only part of it. I do feel disconnected there, I have posted things and waited days for a response and sometimes no response. (Kara, Stagehand)

Students benefited from having a space for observing and a separate space for sharing. Multiple contexts help to facilitate social learning through both observation and direct experiences (Lave \& Wenger, 1991; Wenger, 1998).

\section{No backstage online Facebook presence}

Three students reported not having a backstage online presence on Facebook. The reasons cited were not having a Facebook account, not knowing about the university or class Facebook pages, or not considering themselves social people. One cameo who did not consider herself a social person described herself: "I am not really a joiner though, like in general, I don't join groups." This student preferred to discuss her learning experience with her face-to-face co-workers and clients. Meanwhile, another cameo was a shift-worker. She could only study during the hours when her classmates were most likely sleeping, therefore both her front stage presence and backstage presence were minimal. These caveats remind us that not all students are social learners or live in circumstances that afford online social learning experiences. Similarly, it is unreasonable to expect that all students want an online Facebook presence to support their learning experience. As illustrated in the example above, some learners support their social learning experience through offline relationships and this could be another backstage worth exploring (see for example Gilmore, 2014; Gilmore, 2017; Livingstone \& Sefton-Green, 2016).

\section{Conclusion}

By using the theatre metaphor, I was able to capture the specific ways university students' online learning practices differ across settings, time, and audience. This analytical approach revealed useful insights in explaining why students are absent from a class's discussion board and what they alternatively do to learn course content. Absence from the front stage may not be an absence from learning; rather, the act of being absent affords actors the control to escape, or buffer oneself, from deterministic demands (Goffman, 1959). Some students avoided the front stage discussion board because the audience was too slow, too harsh, and too formal. The backstage online audience solved these problems of the front stage, which made this a more attractive location. Students may need spaces where control and content are student-driven. The challenge for teachers and universities is to develop curriculum with the backstage in mind. 
This study employed a dramaturgical approach to examine how online students perform class-related tasks in spaces other than those designed and monitored by the university. Such an approach allows for careful investigation and analysis of how setting, time, and audience impact online students' learning experience. While not every student used Facebook for university purposes, a closer examination of the backstage online in this psychology class reveals how Facebook facilitates some students' social learning experiences, a finding that can apply to various forms of social media and collaborative technologies outside of an LMS. 


\section{References}

Arouri, Y. (2015). How Jordanian university students perceive the opportunities and challenges of using Facebook as a supplementary learning resource? International Journal of Emerging Technologies in Learning (iJET), 10(1), 46. http://doi.org/10.3991/ijet.v10i1.4265

Bicen, H., \& Cavus, N. (2011). Social network sites usage habits of undergraduate students: Case study of Facebook. Procedia-Social and Behavioral Sciences, 28, 943-947. http://doi.org/10.1016/j.sbspro.2011.11.174

Bosch, T. E. (2009). Using online social networking for teaching and learning: Facebook use at the University of Cape Town. Communication, 35(2), 185-200. http://doi.org/10.1080/02500160903250648

Bowman, N. D., \& Akcaoglu, M. (2014). “I see smart people!”: Using Facebook to supplement cognitive and affective learning in the university mass lecture. The Internet and Higher Education, 23, 1-8. http://doi.org/10.1016/j.iheduc.2014.05.003

Braun, V., \& Clarke, V. (2006). Using thematic analysis in psychology. Qualitative Research in Psychology, 3(2), 77-101.

Bullingham, L., \& Vasconcelos, A. C. (2013). "The presentation of self in the online world": Goffman and the study of online identities. Journal of Information Science, 39(1), 101112. http://doi.org/10.1177/0165551512470051

Catalano, A. (2015). The effect of a situated learning environment in a distance education information literacy course. The Journal of Academic Librarianship, 41(5), 653-659. http://doi.org/10.1016/j.acalib.2015.06.008

Chaiklin, S., \& Lave, J. (Eds.). (1993). Understanding practice: perspectives on activity and context. Cambridge University Press.

Collins, A., Brown, J. S., \& Newman, S. E. (1989). Cognitive apprenticeship: Teaching the crafts of reading, writing, and mathematics. In L. B. Resnick (Ed.), Knowing, learning, and instruction: Essays in honor of Robert Glaser (pp. 453-494). Lawrence Erlbaum Associates.

Cuesta, M., Eklund, M., Rydin, I., \& Witt, A.-K. (2016). Using Facebook as a co-learning community in higher education. Learning, Media and Technology, 41(1), 55-72. http://doi.org/10.1080/17439884.2015.1064952

Denzin, N. K. (1989). The research act: A theoretical introduction to sociological methods (3rd ed). Prentice Hall.

DiVall, M. V., \& Kirwin, J. L. (2012). Using Facebook to facilitate course-related discussion between students and faculty members. American Journal of Pharmaceutical Education, 76(2). doi: 10.5688/ajpe76232

Donlan, L. (2014). Exploring the views of students on the use of Facebook in university teaching and learning. Journal of Further and Higher Education, 38(4), 572-588. http://doi.org/10.1080/0309877X.2012.726973 
A Dramaturgical Examination of Online University Student Practices in a Second Year Psychology Class

English, R. M., \& Duncan-Howell, J. A. (2008). Facebook goes to college: Using social networking tools to support students undertaking teaching practicum. Journal of Online Learning and Teaching, 4(4), 596-601.

Gilmore, D. (2014). Goffman's front stage and backstage behaviors in online education. Journal of Learning Analytics, 1(3), 187-190.

Gilmore, D. (2017). Where and with whom do students learn in an online university subject? A multiple case study analysis. Swinburne University.

Goffman, E. (1959). Presentation of self in everyday life. Double Day Anchor Books.

Hogan, B. (2010). The presentation of self in the age of social media: Distinguishing performances and exhibitions online. Bulletin of Science, Technology \& Society, 30(6), 377-386. http://doi.org/10.1177/0270467610385893

Hyde-Clarke, N. (2013). Facebook and public debate: An informal learning tool for the youth. Journal of African Media Studies, 5(2), 131-148.

Junco, R. (2014). iSpy: Seeing what students really do online. Learning, Media and Technology, 39(1), 75-89. http://doi.org/10.1080/17439884.2013.771782

Lave, J., \& Wenger, E. (1991). Situated learning: Legitimate peripheral participation. Cambridge University Press.

Livingstone, S. M., \& Sefton-Green, J. (2016). The class: Living and learning in the digital age. New York University Press.

Lin, P.-C., Hou, H.-T., Wang, S.-M., \& Chang, K.-E. (2013). Analyzing knowledge dimensions and cognitive process of a project-based online discussion instructional activity using Facebook in an adult and continuing education course. Computers \& Education, 60(1), 110-121. http://doi.org/10.1016/j.compedu.2012.07.017

Livingstone, S. M., \& Sefton-Green, J. (2016). The class: Living and learning in the digital age. New York University Press.

Markham, A. N., \& Baym, N. K. (Eds.). (2009). Internet inquiry: Conversations about method. Sage Publications.

Masood, K., Ahmed, B., Choi, J., \& Gutierrez-Osuna, R. (2012). Consistency and validity of self-reporting scores in stress measurement surveys. In Engineering in Medicine and Biology Society (EMBC), 2012 Annual International Conference of the IEEE (pp. 48954898). IEEE. Retrieved from http://ieeexplore.ieee.org/xpls/abs_all.jsp?arnumber=6347091

Meskill, M, Sadykova G. (2017). The presentation of self in everyday ether: A corpus analysis of student self-tellings in online graduate courses. Online Learning, 11(3), 123-138. http://dx.doi.org/10.24059/olj.v11i3.1723

Pearson, E. (2009). All the World Wide Web's a stage: The performance of identity in online social networks. First Monday, 14(3). http://doi.org/10.5210/fm.v14i3.2162

Phillips, S. (2007). A brief history of Facebook. The Guardian. Retrieved from https://www.theguardian.com/technology/2007/jul/25/media.newmedia

Prescott, J., Wilson, S., \& Becket, G. (2013). Facebook use in the learning environment: do students want this? Learning, Media and Technology, 38(3), 345-350. 
A Dramaturgical Examination of Online University Student Practices in a Second Year Psychology Class

Rambe, P. (2012). Critical discourse analysis of collaborative engagement in Facebook postings. Australasian Journal of Educational Technology, 28(2), 295-314.

Roblyer, M. D., McDaniel, M., Webb, M., Herman, J., \& Witty, J. V. (2010). Findings on Facebook in higher education: A comparison of college faculty and student uses and perceptions of social networking sites. The Internet and Higher Education, 13(3), 134140. http://doi.org/10.1016/j.iheduc.2010.03.002

Rogoff, B., \& Lave, J. (Eds.). (1984). Everyday cognition: Its development in social context. Harvard University Press.

Ross, D. A. R. (2007). Backstage with the knowledge boys and girls: Goffman and distributed agency in an organic online community. Organization Studies, 28(3), 307-325. http://doi.org/10.1177/0170840607076000

Ru-Chu, S. (2013). Effect of using Facebook to assist English for Business Communication course instruction. TOJET: The Turkish Online Journal of Educational Technology, $12(1), 52-59$.

Selwyn, N. (2009). Faceworking: Exploring students' education-related use of Facebook. Learning, Media and Technology, 34(2), 157-174.

Staines, Z., \& Lauchs, M. (2013). Students' engagement with Facebook in a university undergraduate policing unit. Australasian Journal of Educational Technology, 29(6), 792-805.

Stake, R. E. (1995). The art of case study research. Sage Publications.

Trammell, K. D., \& Keshelashvili, A. (2005). Examining the new influencers: A selfpresentation study of A-list blogs. Journalism \& Mass Communication Quarterly, 82(4), 968-982.

Vygotsky, L. S. (1978). Mind in society: The development of higher psychological processes. Harvard University Press.

Wenger, E. (1998). Communities of practice: Learning, meaning, and identity. Cambridge University Press.

Stake, R. E. (1995). The art of case study research. Sage Publications.

Waller, V., Farquharson, K., \& Dempsey, D. (2016). Qualitative social research: Contemporary methods for the digital age. Sage Publications. 